\title{
MINUMAN BERKALORI DAN KONTRIBUSINYA TERHADAP TOTAL ASUPAN ENERGI REMAJA DAN DEWASA
}

\author{
(Calorie Beverages and It's Contribution to the Total Energy Intake \\ in Adolescents and Adults)
}

\author{
Ni Made Putria Sukma Febriyani ${ }^{1}$, Hardinsyah ${ }^{1}$, dan Dodik Briawan ${ }^{1 *}$ \\ ${ }^{1}$ Departemen Gizi Masyarakat, Fakultas Ekologi Manusia (FEMA), Institut Pertanian Bogor, \\ Jl. Raya Darmaga, 16680
}

\begin{abstract}
The objective of this research was to analyze energy intake from calorie beverages (EICB) and it's contribution to the total energy intake of adolescents and adults. The research was carried out through analyzing a data set of THIRST (The Indonesian Regional Hydration Study) collected in 2008 and 2009 by applying a crossectional study design among 606 adolescents (male and female aged 15-18 yrs) and 594 adults (male and female aged 25-55 yrs) in North Jakarta, West Bandung, Surabaya, Malang, Makasar and Malino. Data processing and analysis were conducted in Bogor in April-June 2011. The results showed that the mean EICB among adolescents was $420 \pm 406 \mathrm{kcal} /$ day and among adults was $450 \pm 382 \mathrm{kcal} /$ day, which is $21.2 \%$ and 23.4\% of the total energy intake (TEI) of adolescents and adults respectively. EICB was moderately associated with TEl of adolescents $(r=0.58, p<0.05)$ and adults $(r=0.51, p<0.05)$, and of both adolescents and adults $(r=0.54$ and $p<0.05)$. Further studies are required to analyze causal relationship between EICB and obesity, and other possible adverse effects among Indonesians.
\end{abstract}

Key words: calorie beverages, adolescents, adults, and energy intake

\begin{abstract}
ABSTRAK
Tujuan penelitian adalah menganalisis asupan energi dari minuman berkalori dan kontribusinya terhadap total asupan energi. Data penelitian ini menggunakan data THIRST (The Indonesian Regional Hydration Study) yaitu studi cross-sectional tahun 2008 dan 2009 pada 606 remaja (15-18 tahun) and 594 dewasa (25-55 tahun) di Jakarta Utara, Bandung Barat, Surabaya, Malang, Makasar dan Malino. Data diolah dan dianalisis di Bogor pada bulan April-Juni 2011. Hasil penelitian menunjukkan rata-rata asupan energi dari minuman berkalori adalah $420 \pm 406 \mathrm{kkal} /$ hari pada remaja dan $450 \pm 382 \mathrm{kkal} / \mathrm{hari}$ pada usia dewasa, atau berturut-turut $21.2 \%$ dan $23.4 \%$ dari total asupan energi. Asupan energi minuman tersebut secara signifikan berhubungan dengan total asupan energi, baik pada kelompok remaja $(r=0.58, p<0.05)$ maupun dewasa $(r=0.51, p<0.05)$, atau pada keduanya $(r=0.54$ and $p<0.05$ ). Hal tersebut kemungkinan dapat menyebabkan kelebihan energi, kegemukan, dan kemungkinan efek negatif lainnya.
\end{abstract}

Kata kunci: minuman berkalori, remaja, dewasa, asupan energi

"Korespondensi: Departemen Gizi Masyarakat, Fakultas Ekologi Manusia (FEMA), Institut Pertanian Bogor, Jl. Raya Darmaga, 16680. Tel: 0251 - 8621258; Fax: 0251 - 8622276; Email: dbriawan@yahoomail.com 


\section{PENDAHULUAN}

Zat gizi, termasuk air merupakan salah satu faktor penting yang menentukan tingkat kesehatan dan fungsi kognitif. Manusia dapat memenuhi kebutuhan zat gizi melalui asupan beragam makanan dan minuman. Dalam istilah promosi pesan gizi saat ini disebut pemenuhan gizi seimbang (balance diet) bagi setiap orang.

Dalam hal minuman, ketidaktahuan mengenai pemilihan minuman dapat berdampak buruk pada kelebihan energi. Penelitian yang dilakukan Bleich et al. (2009) di Amerika Serikat menunjukkan bahwa minuman berkalori (mengandung gula) menyumbang asupan energi yang signifikan. Dua pertiga orang dewasa $(63 \%)$ mengonsumsi minuman berkalori ratarata sebesar $293 \mathrm{kkal} / \mathrm{hari}$. Penduduk dewasa muda merupakan golongan dengan prevalensi tertinggi (72\%) mengonsumsi minuman berkalori dengan ratarata asupan $289 \mathrm{kkal} / \mathrm{hari}$. Konsumsi minuman seperti jus dan bersoda menyumbang $81 \%$ dari peningkatan asupan energi dari minuman berkalori.

Pada populasi besar, asupan energi dari minuman berkalori sudah mencapai $20.1 \%$ pada remaja dan $22.3 \%$ untuk dewasa dari asupan energi di Meksiko (Barquera et al. 2008). Kalori dalam minuman sudah terdaftar pada nutrition facts, namun kebanyakan orang belum banyak menyadari bahwa minuman berkalori memiliki kontribusi untuk asupan harian (Walker 2006).

Meskipun minuman berkalori komersial mencantumkan energi pada labelnya, tetapi minuman ini memiliki kontribusi terhadap asupan energi (Walker 2006). Sampai saat ini di Indonesia belum ada penelitian tentang asupan energi dari minuman berkalori. Oleh karena itu tujuan penelitian ini adalah mengetahui berbagai jenis minuman berkalori, asupan energi dari minuman berkalori, serta menganalisis hubungannya dengan total asupan energi pada remaja dan dewasa di Indonesia.

\section{METODE}

\section{Desain, Tempat, Waktu dan Subjek Penelitian}

Penelitian dilakukan dengan mengolah sebagian data dari penelitian mengenai Kebiasaan Minum dan Status Hidrasi pada Remaja dan Dewasa di Dua Wilayah Ekologi Berbeda yang dilaksanakan oleh tim THIRST (The Indonesian Regional Hydration Study). Desain penelitian THIRST adalah cross sectional study dengan wilayah penelitian di Bandung Barat (Jawa Barat), Jakarta Utara (DKI Jakarta), Malang dan Surabaya (Jawa Timur), serta Malino dan Makasar (Sulawesi Selatan). Pengumpulan data dilakukan dari akhir tahun 2008 sampai awal tahun 2009. Pengolahan, analisis, dan interpretasi data dilakukan pada bulan April-Juni 2011 di Bogor.

Sampel penelitian adalah remaja berusia 15-18 tahun dan dewasa berusia 25-55 tahun (laki-laki dan perempuan) yang bermukim di lokasi penelitian. Jumlah subjek dihitung berdasarkan rumus perhitungan jumlah subjek minimal penelitian cross sectional study, subjek untuk tiap kelompok (jenis kelamin/kelompok umur/wilayah), menggunakan formula: $\mathrm{n} \geq \mathrm{z}_{\mathrm{a} 2} \times \mathrm{p}(1-\mathrm{p}) / \mathrm{d} 2$ dengan pertimbangan $\mathrm{z}_{\mathrm{a} 2}=1.96, \mathrm{~d}=0.1$ dan proporsi dehidrasi $(\mathrm{p})$ diasumsikan sebesar 30\% (Manz \& Wentz 2005). Sehingga jumlah subjek minimal untuk tiap jenis kelamin (laki/perempuan) dan kelompok umur (remaja/ dewasa) di masing-masing lokasi penelitian adalah 41 , yang dibulatkan menjadi 50 untuk mengantisipasi kehilangan subjek dan meningkatkan ketepatan penelitian. Mempertimbangkan dua kelompok jenis kelamin, dua kelompok umur dan enam lokasi penelitian, maka jumlah total sampel 1200 subjek.

Kelompok usia remaja (15-18 tahun) merupakan pelajar SMU, maka cara penarikan subjek relatif mudah dilakukan dengan memilih SMU dengan jumlah siswa yang banyak di masing-masing lokasi penelitian. Pemilihan subjek dewasa dilakukan dengan cara memilih guru dan karyawan sekolah bermukim di lokasi penelitian serta orang dewasa disekitar sekolah.

\section{Jenis dan Cara Pengumpulan Data}

Data yang digunakan dalam penelitian ini sebagian merupakan data sekunder berbentuk electronic file yang rinciannya adalah sebagai berikut (Tabel 1).

\section{Pengolahan dan Analisis Data}

Data yang diperoleh diolah dan dianalisis dengan menggunakan program komputer Microsoft Office Excel dan SPSS 16 for Windows. Pengolahan

Tabel 1. Aspek, Cakupan Data, dan Metode yang Digunakan dalam Penelitian

\begin{tabular}{|c|c|c|}
\hline Aspek & Cakupan & Metode \\
\hline Sosial-ekonomi-demografi & $\begin{array}{l}\text { Karakteristik individu dan keluarga (umur, jenis kelamin, } \\
\text { ukuran, pengeluaran minum dan pengeluaran keluarga) }\end{array}$ & $\begin{array}{l}\text { Kuesioner diisi sendiri diawali } \\
\text { penjelasan }\end{array}$ \\
\hline Aktivitas fisik & $\begin{array}{l}\text { Jenis, durasi dan frekuensi aktivitas fisik dan olahraga } \\
\text { selama satu minggu }\end{array}$ & $\begin{array}{l}\text { Kuesioner diisi sendiri diawali } \\
\text { penjelasan }\end{array}$ \\
\hline Status gizi & Berat dan tinggi badan & $\begin{array}{l}\text { Pengukuran dengan timbangan } \\
\text { badan dan microtoise }\end{array}$ \\
\hline $\begin{array}{l}\text { Asupan makanan dan } \\
\text { minuman }\end{array}$ & $\begin{array}{l}\text { Jenis, jumlah, dan sumber air minum dan minuman } \\
\text { selama tujuh hari }\end{array}$ & Wawancara (semi FFQ) \\
\hline
\end{tabular}


data diawali dengan pemeriksaan kelengkapan efile data. Semua data subjek dapat digunakan untuk analisis (1200 subjek).

Asupan energi total dan energi dari minuman berkalori dihitung berdasarkan kandungan energi dalam DKBM, kandungan gizi makanan dan minuman komersial berlabel menggunakan kandungan tercantum pada label. Asupan energi dibandingkan dengan kebutuhan sehingga dapat dilakukan penilaian tingkat asupan energi terhadap kebutuhan.

Penilaian tingkat kecukupan energi diklasifikasikan menjadi tiga, yaitu rendah $(<85 \%)$, cukup (85-115\%), dan tinggi ( $\geq 115 \%)$. Penilaian asupan minuman berkalori menggunakan batas penambahan gula $10 \%$ pada makanan (WHO 2003). Angka kecukupan energi rata-rata untuk remaja dan dewasa adalah 2000 kkal, sehingga asupan gula disarankan memiliki kontribusi < 200 kkal. Asupan gula dari minuman dibagi jadi tiga, yaitu rendah (<100 kkal), sedang (100-200 kkal), dan tinggi (>200 kkal). Aktivitas fisik subjek selama 24 jam dinyatakan dalam PAL (Physical Activity Level) atau tingkat aktivitas fisik. PAL dibagi menjadi tiga kategori yaitu ringan, sedang, dan berat (FAO/WHO/UNU 2001). PAL merupakan besarnya energi yang dikeluarkan per kilogram berat badan dalam 24 jam (kkal/kg BB).

Pengukuran status gizi pada remaja dan dewasa menggunakan perbandingan Indeks Massa Tubuh (IMT). Status gizi remaja dihitung berdasarkan standar penilaian IMT menurut umur. Nilai indeks massa tubuh (IMT) yang normal untuk dewasa berkisar antara 18.5-24.9 (WHO 2007).

Kebutuhan energi dihitung berdasarkan besarnya energi metabolisme basal (EMB) mengguna- kan oxford equation dalam WNPG VIII 2004. Kebutuhan individu dalam penelitian ini diperoleh dengan menghitung energi sesuai dengan berat badan aktual dikali metabolisme energi basal (EBM) yang dikoreksi dengan PAL dan energi makanan thermal (10\% EBM).

Analisis deskriptif dilakukan terhadap data karakteristik individu, karakteristik sosial ekonomi keluarga, aktivitas fisik, status gizi, dan asupan makanan dan minuman. Uji statistik menggunakan uji t antara kelompok usia (remaja dan dewasa), jenis kelamin (perempuan dan laik-laki); serta uji Pearson untuk mengetahui hubungan asupan minuman berenergi dengan total asupan energi.

\section{HASIL DAN PEMBAHASAN}

\section{Sosial Ekonomi, Aktivitas Fisik dan Status Gizi}

Proporsi laki-laki dan perempuan, serta proporsi remaja dan dewasa dipilih secara proporsional seperti yang direncanakan pada saat sampling. Rata-rata umur subjek remaja dan dewasa pada penelitian ini masing-masing $15.9 \pm 0.9$ dan $40.3 \pm 9.4$ tahun. Besar keluarga subjek baik pada subjek remaja maupun pada subjek dewasa sama yaitu $5 \pm 2$ orang. Nilai pengeluaran minuman pada dewasa (Rp $95641 \pm 108$ 045) lebih tinggi dibanding pada remaja (Rp $68667 \pm 52$ 219). Pengeluaran rumah tangga tertinggi subjek ada pada rentang $\mathrm{Rp}$ 1000000 - 1999999 sebesar 42.2\% (Tabel 2). Uji statistik menunjukkan bahwa besar keluarga, pengeluaran minum, dan pengeluaran rumah tangga subjek terdapat perbedaan yang nyata (signifikan) antara remaja dan dewasa $(p<0.05)$.

Tabel 2. Sebaran Subjek menurut Karakteristik Sosial Ekonomi

\begin{tabular}{|c|c|c|c|c|}
\hline No & Karakteristik & Remaja & Dewasa & Total \\
\hline 1 & Umur (tahun) & $15.9 \pm 0.9$ & $40.3 \pm 9.4$ & $28.0 \pm 13.9$ \\
\hline 2 & $\begin{array}{l}\text { Jenis kelamin } \\
\text { a. Laki-laki } \\
\text { b. Perempuan }\end{array}$ & $\begin{array}{l}301(49.7) \\
305(50.3)\end{array}$ & $\begin{array}{l}277(46.6) \\
317(53.4)\end{array}$ & $\begin{array}{l}578(48.2) \\
622(51.8)\end{array}$ \\
\hline & Jumlah & $606(100.0)$ & $594(100.0)$ & $1200(100.0)$ \\
\hline 3 & $\begin{array}{l}\text { Besar keluarga } \\
\text { a. } 2-4 \text { orang } \\
\text { b. } 5-6 \text { orang } \\
\text { c. } \geq 7 \text { orang }\end{array}$ & $\begin{array}{r}5 \pm 2 \\
247(40.7) \\
280(46.2) \\
79(13.1)\end{array}$ & $\begin{array}{r}5 \pm 2 \\
310(52.2) \\
201(33.8) \\
83(14.0)\end{array}$ & $\begin{array}{l}5 \pm 2 \\
548(45.7) \\
500(41.6) \\
152(12.7)\end{array}$ \\
\hline & Jumlah & 606 (100.0) & $594(100.0)$ & $1200(100.0)$ \\
\hline 4 & $\begin{array}{l}\text { Pengeluaran minuman (Rp/bulan) } \\
\text { a. } \leq 100000 \\
\text { b. }>100000\end{array}$ & $\begin{array}{r}68667 \pm 52219 \\
483(79.7) \\
123(20.3)\end{array}$ & $\begin{array}{r}95641 \pm 108045 \\
410(69.0) \\
184(31.0)\end{array}$ & $\begin{array}{r}82019 \pm 85624 \\
893(74.4) \\
307(25.6)\end{array}$ \\
\hline & Jumlah & 606 (100.0) & $594(100.0)$ & $1200(100.0)$ \\
\hline 5 & $\begin{array}{l}\text { Pengeluaran rumah tangga (Rp/bulan) } \\
\text { a. }<1 \text { juta } \\
\text { b. } 1-1.9 \text { juta } \\
\text { c. } 2-3.9 \text { juta } \\
\text { d. } \geq 4 \text { juta }\end{array}$ & $\begin{array}{r}157(25.9) \\
271(44.7) \\
146(24.1) \\
32(5.3)\end{array}$ & $\begin{array}{r}133(22.4) \\
238(40.1) \\
156(26.3) \\
67(11.2)\end{array}$ & $\begin{array}{r}291(24.2) \\
506(42.2) \\
326(27.2) \\
77(6.4)\end{array}$ \\
\hline & Jumlah (\%) & 606 (100.0) & $594(100.0)$ & $1200(100.0)$ \\
\hline
\end{tabular}


Nilai PAL subjek bervariasi antara 1.2 - 3.0 (ringan sampai berat). Pada Gambar 1 disajikan sebaran subjek menurut tingkat aktivitas fisik pada remaja dan dewasa. Secara keseluruhan aktivitas fisik subjek pada umumnya tergolong ringan (67.5\%). Dibanding dewasa, remaja lebih banyak melakukan aktivitas sedang dan berat, baik pada laki-laki maupun perempuan $(p<0.05)$. Hal ini sejalan dengan temuan Weiss et al. (2007).

Secara keseluruhan, subjek pada penelitian ini memiliki status gizi normal (61.3\%). Namun prevalensi gemuk jauh lebih tinggi pada dewasa (50.5\%) dibanding remaja (15.7\%) (Tabel 3), yang didukung oleh fakta sebelumnya bahwa orang dewasa lebih banyak melakukan aktivitas ringan. Hasil uji korelasi pearson membuktikan hubungan terbalik antara aktivitas fisik dan status gizi $(r=-0.16, p<0.05)$. Ini sejalan dengan hasil penelitian Weiss et al. (2007) bahwa IMT dan aktivitas fisik berhubungan terbalik.

\section{Jenis Minuman dan Minuman Berkalori}

Jenis minuman subjek bervariasi dengan jenis minuman yang paling dominan adalah air putih. Sebanyak $51.5 \%$ subjek remaja laki-laki lebih menyukai air putih dan $58.7 \%$ pada remaja perempuan. Alasan utama remaja menyukai minuman selain air karena rasa. Persentase kesukaan terhadap air putih pada dewasa laki-laki dan perempuan yaitu $75.8 \%$ dan $80.4 \%$. Alasan utama lebih menyukai selain air putih pada subjek dewasa adalah rasa, sebesar 70.2\% pada laki-laki dan $82.3 \%$ pada perempuan. Penelitian Malik et al. (2006) di USA menunjukkan asupan minuman berkalori meningkat $135 \%$ antara tahun 1977 dan 2001. Yang termasuk dalam kelompok minuman ini meliputi minuman ringan soda bersama dengan minuman gula manis lainnya seperti minuman buah, limun, dan es teh. Istilah minuman ringan soda mencakup carbonated beverages seperti cola.

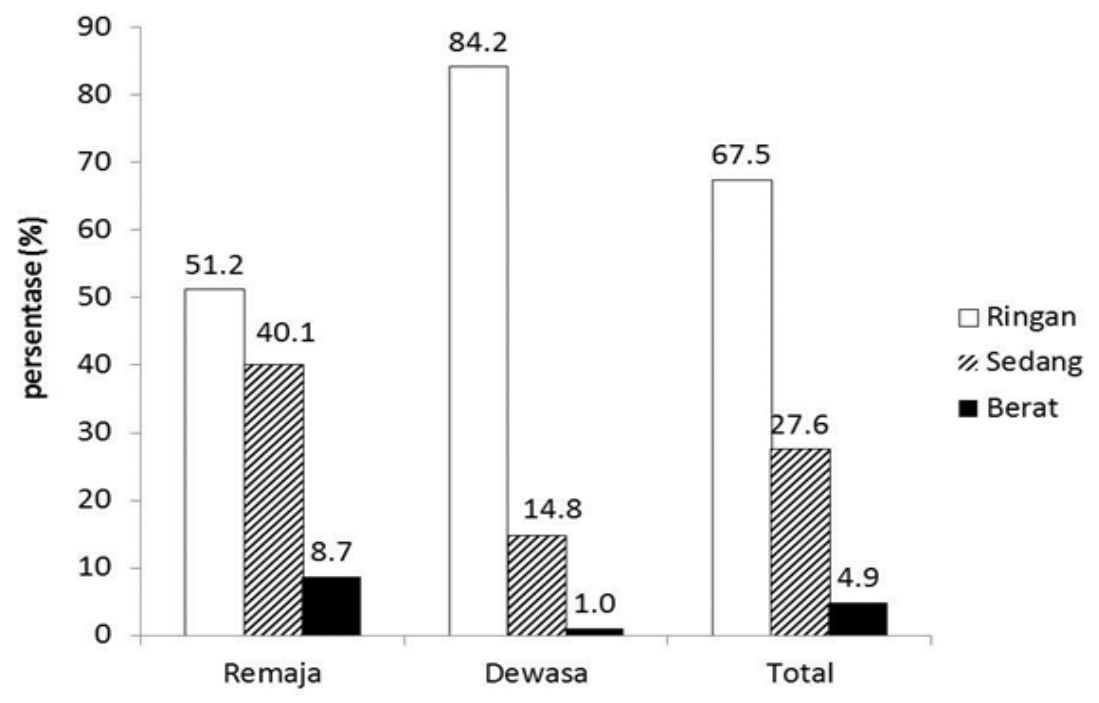

Gambar 1. Persentase Kategori Aktivitas Fisik

Tabel 3. Sebaran Subjek berdasarkan Status Gizi

\begin{tabular}{clrrr}
\hline No & \multicolumn{1}{c}{ Subjek } & Remaja [n (\%)] & Dewasa [n (\%)] & \multicolumn{1}{c}{ Total [n (\%)] } \\
\hline 1 & Laki-laki & $28(9.3)$ & $11(3.9)$ & $39(6.7)$ \\
& a. Kurus & $224(74.4)$ & $143(51.6)$ & $367(63.5)$ \\
& b. Normal & $49(16.3)$ & $123(44.5)$ & $172(29.8)$ \\
& C. Gemuk & $301(100.0)$ & $277(100.0)$ & $578(100.0)$ \\
& Jumlah & & & \\
2 & $18(5.9)$ & $13(4.1)$ & $31(5.0)$ \\
Perempuan & $241(79.0)$ & $127(40.1)$ & $368(59.2)$ \\
a. Kurus & $46(15.1)$ & $177(55.8)$ & $223(35.8)$ \\
b. Normal & $305(100.0)$ & $317(100.0)$ & $622(100.0)$ \\
C. Gemuk & & & \\
Jumlah & $46(7.6)$ & $24(4.0)$ & $70(5.8)$ \\
Laki-laki + Perempuan & $465(76.7)$ & $270(45.5)$ & $735(61.3)$ \\
a. Kurus & $95(15.7)$ & $300(50.5)$ & $395(32.9)$ \\
b. Normal & $606(100.0)$ & $594(100.0)$ & $1200(100.0)$ \\
\hline & C. Gemuk & & & \\
Jumlah &
\end{tabular}


Pada penelitian Bleich et al. (2009) minuman berkalori kedalam enam jenis, yaitu minuman bergula, jus, minuman diet, susu (termasuk yang memiliki rasa), kopi atau teh, dan alkohol. Minuman ber- gula terdiri dari soda, minuman olahraga, minuman berperisa buah, minuman rendah kalori, teh yang dimaniskan, dan minuman yang dimaniskan lainnya. Tabel 4 berikut menunjukkan sebaran subjek ber-

Tabel 4. Sebaran Subjek berdasarkan Konsumsi Minuman Berkalori menurut Jenis Kelamin

\begin{tabular}{|c|c|c|c|c|}
\hline No & Jenis Minuman & Remaja [n (\%)] & Dewasa [n (\%)] & Total [n (\%)] \\
\hline & Laki-laki & & & \\
\hline 1 & Teh tanpa kemasan & $198(65.8)$ & $107(38.6)$ & $305(52.8)$ \\
\hline 2 & Susu kemasan & $179(59.4)$ & $111(40.1)$ & $299(51.7)$ \\
\hline 3 & Jus/sari buah tanpa kemasan & $98(32.6)$ & $121(43.7)$ & 219 (37.9) \\
\hline 4 & Minuman serbuk aneka rasa & $139(46.2)$ & $52(18.8)$ & $191(33.0)$ \\
\hline 5 & Aneka es buah/campur/kelapa & $118(39.2)$ & $71(25.6)$ & $189(32.7)$ \\
\hline 6 & Minuman berkarbonasi & $127(42.2)$ & $51(18.4)$ & $178(30.8)$ \\
\hline 7 & Jus/sari buah kemasan & $86(28.6)$ & $45(16.2)$ & $131(22.7)$ \\
\hline 8 & Teh kemasan & 102 (33.9) & $27(9.7)$ & $129(22.3)$ \\
\hline 9 & Kopi tanpa kemasan & $38(12.6)$ & $62(22.4)$ & $100(17.3)$ \\
\hline 10 & Kopi kemasan & $48(15.9)$ & $37(13.4)$ & $85(14.7)$ \\
\hline 11 & Minuman jelly & $71(23.6)$ & $10(3.6)$ & $81(14.0)$ \\
\hline 12 & Sirup & $53(17.6)$ & $27(9.7)$ & $80(13.8)$ \\
\hline 13 & Minuman lainnya & $16(8.6)$ & $45(16.2)$ & $71(12.3)$ \\
\hline 14 & Susu tanpa kemasan & $32(10.6)$ & $36(13.0)$ & $68(11.8)$ \\
\hline 15 & Minuman elektrolit & $28(9.3)$ & $31(11.2)$ & $59(10.2)$ \\
\hline 16 & Susu kedelai & $6(2.0)$ & $10(3.6)$ & $16(2.8)$ \\
\hline \multirow[t]{2}{*}{17} & Yogurt/probiotik & $12(4.0)$ & $3(1.1)$ & $15(2.6)$ \\
\hline & Perempuan & & & \\
\hline 1 & Teh tanpa kemasan & $181(59.3)$ & $152(47.9)$ & $333(53.5)$ \\
\hline 2 & Susu kemasan & $184(60.3)$ & $133(42.0)$ & $317(51.0)$ \\
\hline 3 & Jus/sari buah tanpa kemasan & $133(43.6)$ & $156(53.1)$ & $289(46.5)$ \\
\hline 4 & Aneka es buah/campur/kelapa & $134(43.9)$ & $90(30.6)$ & $224(36.0)$ \\
\hline 5 & Minuman serbuk aneka rasa & $152(49.8)$ & $36(12.2)$ & $188(30.2)$ \\
\hline 6 & Minuman berkarbonasi & $120(39.3)$ & $63(21.4)$ & $183(29.4)$ \\
\hline 7 & Jus/sari buah kemasan & $100(32.8)$ & $70(23.8)$ & $170(27.3)$ \\
\hline 8 & Teh kemasan & $125(41.0)$ & $32(10.1)$ & $157(25.2)$ \\
\hline 9 & Sirup & $70(23.0)$ & $36(12.2)$ & $106(17.0)$ \\
\hline 10 & Jamu dan minuman herbal & $26(8.5)$ & $58(19.7)$ & $84(13.5)$ \\
\hline 11 & Susu tanpa kemasan & $34(11.1)$ & $49(16.7)$ & $83(13.3)$ \\
\hline 12 & Minuman jelly & $60(19.7)$ & $8(2.7)$ & $68(10.9)$ \\
\hline 13 & Kopi kemasan & $18(5.9)$ & $42(13.2)$ & $60(9.6)$ \\
\hline 14 & Kopi tanpa kemasan & $19(6.2)$ & 37 (11.7) & $56(9.0)$ \\
\hline 15 & Minuman lainnya & $22(7.3)$ & $34(11.6)$ & $56(9.0)$ \\
\hline 16 & Yogurt/probiotik & $15(4.9)$ & $15(4.7)$ & $30(4.8)$ \\
\hline \multirow[t]{2}{*}{17} & Susu kedelai & $2(0.7)$ & $11(3.5)$ & $13(2.1)$ \\
\hline & $\underline{\text { Laki-laki + Perempuan }}$ & & & \\
\hline 1 & Teh tanpa kemasan & 379 (62.5) & $259(43.6)$ & $638(53.2)$ \\
\hline 2 & Susu kemasan & $363(60.0)$ & $244(41.1)$ & $607(50.6)$ \\
\hline 3 & Jus/sari buah tanpa kemasan & $231(38.1)$ & $277(46.6)$ & $508(42.3)$ \\
\hline 4 & Aneka es buah/campur/kelapa & $252(41.6)$ & $161(27.1)$ & $413(34.4)$ \\
\hline 5 & Minuman serbuk aneka rasa & $291(48.0)$ & $88(14.8)$ & $379(31.6)$ \\
\hline 6 & Minuman berkarbonasi & $247(40.8)$ & $114(19.2)$ & $361(30.1)$ \\
\hline 7 & Jus/sari buah kemasan & $186(30.7)$ & $115(19.4)$ & $301(25.1)$ \\
\hline 8 & Teh kemasan & $227(37.5)$ & $59(9.9)$ & $286(23.8)$ \\
\hline 9 & Sirup & $123(20.3)$ & $63(10.6)$ & $186(15.5)$ \\
\hline 10 & Kopi tanpa kemasan & $57(9.4)$ & $99(16.7)$ & $156(13.0)$ \\
\hline 11 & Susu tanpa kemasan & $66(10.9)$ & $85(14.3)$ & $151(12.6)$ \\
\hline 12 & Minuman jelly & $131(21.6)$ & $18(3.0)$ & $149(12.4)$ \\
\hline 13 & Kopi kemasan & $66(10.9)$ & 79 (13.2) & $145(12.1)$ \\
\hline 14 & Minuman lainnya & 54 (9.9) & $103(17.3)$ & $157(13.1)$ \\
\hline 15 & Minuman elektrolit & 48 (7.9) & 65 (10.9) & $113(9.4)$ \\
\hline 16 & Yogurt/probiotik & $27(4.5)$ & $18(3.0)$ & $45(3.8)$ \\
\hline 17 & Susu kedelai & $8(1.3)$ & $213.5)$ & $29(2.4)$ \\
\hline
\end{tabular}


dasarkan konsumsi minuman berkalori pada remaja dan dewasa selama satu minggu.

Pada penelitian ini, jenis minuman berkalori yang terdapat di pasaran dikelompokkan menjadi tujuh belas kategori, yaitu teh kemasan, kopi kemasan, teh tanpa kemasan, kopi tanpa kemasan, minuman berkarbonasi, minuman elektrolit, jus/sari buah kemasan, jus/sari buah tanpa kemasan, minuman serbuk aneka rasa, susu kemasan, susu tanpa kemasan, susu kedelai, yogurt/probiotik, minuman jelly, aneka es buah/campur/kelapa, sirup, serta minuman lainnya.

Lima jenis minuman berkalori yang paling banyak dikonsumsi selama satu minggu oleh subjek remaja yaitu teh tanpa kemasan $(62.5 \%)$, susu kemasan $(62.5 \%)$, minuman serbuk aneka rasa (48.0\%), aneka es buah/campur/kelapa (41.6\%), serta minuman berkarbonasi (40.8\%). Studi Briawan, Sedayu dan Ekayanti (2011) di Bogor menunjukkan kebiasaan minum pada remaja selain dari air putih adalah jenis minuman seperti susu, teh, dan sirup; yaitu berturut-turut sebesar 33\%, 29\% dan 13\% dari total sampel.

Pada kelompok dewasa yaitu jus/sari buah tanpa kemasan (46.6\%), teh tanpa kemasan (43.6\%), susu kemasan (41.1\%), aneka es buah/campur/kelapa (27.1\%), dan jus/sari buah kemasan (19.4\%). Survey pada populasi dewasa di USA menunjukkan total asupan cairan sebesar $28 \%$ dari makanan, 28\% air putih, dan 44\% dari minuman lainnya (Kleiner 1999).

\section{Kontribusi Energi Minuman Berkalori}

Tabel 5 menunjukkan perbandingan asupan energi terhadap kebutuhan energi pada remaja dan dewasa menurut jenis kelamin. Tingkat asupan energi pada remaja laki-laki (67.5\%) lebih rendah dibanding pada remaja perempuan (70.1\%). Pola yang sama juga terjadi pada dewasa.

Asupan energi harian subjek dianalisis berdasarkan sumbernya, dari makanan dan dari minuman (minuman berkalori). Asupan minuman berkalori pada remaja laki-laki sebesar $455 \pm 431 \mathrm{kkal} /$ hari dan pada remaja perempuan $386 \pm 376 \mathrm{kkal} /$ hari; pada dewasa laki-laki $465 \pm 407 \mathrm{kkal} /$ hari dan pada dewasa perempuan $437 \pm 356 \mathrm{kkal} /$ hari (Tabel 5). Pada uji statistik (uji t) menunjukkan bahwa tidak ada perbedaan antara asupan energi minuman berkalori antara remaja dan dewasa $(p>0.05)$. Pada uji statistik untuk remaja perempuan dan laki-laki terdapat perbedaan yang signifikan $(p<0.05)$, namun tidak berbeda pada dewasa laki-laki dan perempuan. Total asupan minuman berkalori pada remaja sebesar 420 kkal sedangkan untuk dewasa sebesar 450 kkal.

Angka asupan energi dari minuman pada studi ini jauh lebih tinggi dibanding asupan energi dari minuman berkalori di Amerika hasil penelitian Bleich et al. (2009), yang mana asupan minuman berkalori pada tahun 1999-2004 sebesar 293 kkal/hari pada semua penduduk dan 289 kkal/hari pada dewasa muda. Kemungkinan karena penelitian tersebut sudah lama (5-10 tahun lalu) atau karena metode recall 24 jam, dimana minuman berkalori underestimated. Hal ini perlu diwaspadai karena ada kecenderungan peningkatan energi dari minuman berkalori di negara maju. Berdasarkan penelitian Malik et al. (2006) di Amerika selama lima tahun terakhir asupan energi dari minuman berkalori

Tabel 5. Perbandingan Asupan Energi dari Makanan dan Minuman terhadap Kebutuhan Energi

\begin{tabular}{|c|c|c|c|c|}
\hline \multirow{2}{*}{ No } & \multirow{2}{*}{ Kategori } & \multicolumn{3}{|c|}{ Asupan Energi } \\
\hline & & Remaja & Dewasa & Total \\
\hline \multirow[t]{7}{*}{1} & Laki-laki & & & \\
\hline & a. Makanan (kkal) & $1645 \pm 902$ & $1526 \pm 597$ & $1588 \pm 773$ \\
\hline & b. Minuman (kkal) & $455 \pm 431$ & $465 \pm 407$ & $593 \pm 718$ \\
\hline & Total asupan (kkal) & $2098 \pm 1043$ & $2012 \pm 734$ & $2181 \pm 1075$ \\
\hline & Kebutuhan energi (kkal) & $3110 \pm 550$ & $2338 \pm 246$ & $2740 \pm 579$ \\
\hline & Tingkat konsumsi (\%) & 67.5 & 86.1 & 79.6 \\
\hline & Kontribusi minuman terhadap total asupan energi (\%) & 21.7 & 23.1 & 27.2 \\
\hline \multirow[t]{7}{*}{2} & Perempuan & & & \\
\hline & a. Makanan (kkal) & $1473 \pm 655$ & $1403 \pm 503$ & $1437 \pm 583$ \\
\hline & b. Minuman (kkal) & $386 \pm 376$ & $437 \pm 356$ & $462 \pm 504$ \\
\hline & Total konsumsi (kkal) & $1859 \pm 775$ & $1839 \pm 637$ & $1900 \pm 790$ \\
\hline & Kebutuhan energi (kkal) & $2651 \pm 412$ & $1857 \pm 146$ & $2246 \pm 502$ \\
\hline & Tingkat konsumsi (\%) & 70.1 & 99.0 & 84.6 \\
\hline & Kontribusi minuman terhadap total asupan energi (\%) & 20.8 & 23.8 & 24.3 \\
\hline \multirow[t]{7}{*}{3} & Laki-laki + Perempuan & & & \\
\hline & a. Makanan (kkal) & $1558 \pm 792$ & $1460 \pm 552$ & $1510 \pm 685$ \\
\hline & b. Minuman (kkal) & $420 \pm 406$ & $450 \pm 382$ & $525 \pm 620$ \\
\hline & Total konsumsi (kkal) & $1978 \pm 925$ & $1919 \pm 689$ & $2035 \pm 948$ \\
\hline & Kebutuhan energi (kkal) & $2879 \pm 537$ & $2081 \pm 312$ & $2484 \pm 594$ \\
\hline & Tingkat konsumsi (\%) & 68.7 & 92.2 & 81.9 \\
\hline & Kontribusi minuman terhadap total asupan energi (\%) & 21.2 & 23.4 & 25.8 \\
\hline
\end{tabular}


meningkat sebesar $83 \mathrm{kkal} /$ orang, dimana 54 kkal/ hari dari jenis minuman soda.

Pada penelitian ini, asupan minuman berkalori pada remaja sedikit lebih rendah dibanding dewasa, ini berbeda dengan pernyataan dari Mann \& Stewart (2007) yang menyatakan bahwa kelompok usia tertentu seperti remaja memiliki asupan minuman berkalori yang tinggi.

Asupan energi dari minuman berkalori untuk remaja yang tertinggi adalah susu kemasan (25.2\%) sebesar 106 kkal, teh tanpa kemasan sebesar 105 kkal (25.0\%), aneka es buah/campur/kelapa (8.1\%) sebesar 34 kkal, jus/sari buah tanpa kemasan (6.7\%) sebesar 28 kkal, dan minuman berkarbonasi (5.5\%) menyumbang energi sebesar $23 \mathrm{kkal}$. Pada subjek dewasa, total asupan minuman berkalori pada dewasa berasal dari teh tanpa kemasan (39.3\%) dengan sumbangan kalori sebesar 177 kkal, kemudian jenis minuman berkalori seperti susu kemasan (18.5\%) sebesar 83 kkal, kopi tanpa kemasan (9.8\%) sebesar 44 kkal, kopi kemasan (9.1\%) sebesar 41 kkal, dan jus/sari buah tanpa kemasan (6.4\%) sebesar 29 kkal.
Hubungan Asupan Energi Minuman Berkalori dengan Total Asupan Energi

Asupan minuman berkalori subjek pada penelitian ini dikelompokkan menjadi tiga, yaitu rendah (<100 kkal), sedang (100-200 kkal), dan tinggi (>200 kkal). Tabel 6 menunjukkan sebaran subjek berdasarkan asupan energi minuman berkalori pada remaja dan dewasa. Sebagian besar subjek mengonsumsi minuman berkalori lebih dari 200 kkal baik pada remaja maupun dewasa. Uji t menunjukkan bahwa asupan minuman berkalori pada remaja dan dewasa baik laki-laki maupun perempuan, tidak terdapat perbedaan yang signifikan $(p>0.05)$.

Tingkat konsumsi energi pada subjek remaja dan dewasa dikategorikan menjadi tiga kelompok, yaitu rendah $(<85 \%)$, cukup $(85-115 \%)$, dan tinggi (>115\%). Tabel 7 menunjukkan hubungan minuman berkalori dengan asupan energi pada remaja dan dewasa.

Total subjek remaja yang mengonsumsi minuman berkalori tinggi namun asupan energinya rendah sebanyak $58.7 \%$, sedangkan pada asupan energi

Tabel 6. Sebaran Subjek berdasarkan Asupan Energi Minuman Berkalori

\begin{tabular}{lrr}
\hline \multicolumn{1}{c}{ Asupan Minuman Berkalori } & Remaja [n (\%)] & Dewasa [n (\%)] \\
\hline Laki-laki & & \\
Rendah (<100 kkal) & $45(15.0)$ & $48(17.3)$ \\
Sedang $(100-200 \mathrm{kkal})$ & $51(16.9)$ & $43(15.5)$ \\
Tinggi $(>200 \mathrm{kkal})$ & $205(68.1)$ & $186(67.2)$ \\
Total & $301(100.0)$ & \\
Perempuan & & \\
\hline Rendah $(<100 \mathrm{kkal})$ & $46(15.1)$ & $52(16.4)$ \\
Sedang $(100-200 \mathrm{kkal})$ & $62(20.3)$ & $53(16.7)$ \\
Tinggi $(>200 \mathrm{kkal})$ & $197(64.6)$ & $212(66.9)$ \\
Total & $305(100.0)$ & $317(100.0)$ \\
Laki-laki + Perempuan & & \\
Rendah $(<100 \mathrm{kkal})$ & $91(15.0)$ & $100(16.8)$ \\
Sedang $(100-200 \mathrm{kkal})$ & $113(18.6)$ & $96(16.2)$ \\
Tinggi $(>200 \mathrm{kkal})$ & $402(66.4)$ & $398(67.0)$ \\
Total & $606(100.0)$ & $594(100.0)$ \\
\hline
\end{tabular}

Tabel 7. Hubungan Minuman Berkalori dengan Asupan Energi pada Remaja dan Dewasa

\begin{tabular}{lcccccc}
\hline \multicolumn{1}{c}{$\begin{array}{c}\text { Intake Minuman } \\
\text { berkalori }\end{array}$} & \multicolumn{3}{c}{ Asupan Energi Remaja (\%) } & \multicolumn{3}{c}{ Asupan Energi Dewasa (\%) } \\
\cline { 2 - 7 } & Rendah (<85\%) & Cukup (85-115\%) & Tinggi (>115\%) & Rendah (<85\%) & Cukup (85-115\%) & Tinggi (>115\%) \\
\hline Laki-laki & & & & & & \\
Rendah (<100 kkal) & 17.3 & 9.3 & 4.8 & 24.5 & 11.2 & 8.2 \\
Sedang (100-200 kkal) & 20.8 & 7.4 & 0.0 & 23.7 & 5.6 & 10.2 \\
Tinggi (>200 kkal) & 61.9 & 83.3 & 95.2 & 51.8 & 83.2 & 81.6 \\
Total & 100.0 & 100.0 & 100.0 & 100.0 & 100.0 & 100.0 \\
Perempuan & & & & & & \\
Rendah (<100 kkal) & 20.3 & 1.9 & 0.0 & 27.1 & 13.3 & 8.9 \\
Sedang (100-200 kkal) & 24.3 & 13.2 & 3.3 & 24.3 & 19.4 & 7.1 \\
Tinggi (>200 kkal) & 55.4 & 84.9 & 96.7 & 48.6 & 67.3 & 83.9 \\
Total & 100.0 & 100.0 & 100.0 & 100.0 & 100.0 & 100.0 \\
Laki-laki + Perempuan & & & & & & \\
Rendah (<100 kkal) & 18.8 & 5.6 & 2.0 & 25.6 & 12.3 & 8.7 \\
Sedang (100-200 kkal) & 22.5 & 10.3 & 2.0 & 24.0 & 12.8 & 8.1 \\
Tinggi (>200 kkal) & 58.7 & 84.1 & 96.0 & 50.4 & 74.9 & 83.2 \\
Total & 100.0 & 100.0 & 100.0 & 100.0 & 100.0 & 100.0 \\
\hline
\end{tabular}


cukup $84.1 \%$, dan pada asupan energi tinggi sebesar $96.0 \%$. Pada laki-laki dewasa, sebanyak $67.1 \%$ mengonsumsi minuman berkalori lebih dari 200 kkal, sedangkan pada perempuan sebanyak $66.9 \%$. Pada ketiga tingkat konsumsi energi (rendah, cukup, tinggi) sebagian besar mengonsumsi minuman berkalori lebih besar dari $200 \mathrm{kkal}$.

Uji pearson digunakan untuk melihat hubunggan antara asupan energi minuman berkalori dengan total asupan energi pada dewasa. Asupan minuman berkalori berhubungan positif dengan total asupan energi dewasa yang signifikan pada $r=0.51(p<0.05)$, sedangkan pada remaja juga berhubungan positif dengan nilai $r=0.58(p<0.05)$. Secara keseluruhan, asupan energi minuman berkalori berhubungan positif dengan total asupan energi pada remaja dan dewasa yang signikan pada nilai $r=0.54(p<0.05)$. Pada remaja, kontribusi asupan minuman berkalori terhadap asupan energi sebesar $21.2 \%$, sedangkan dewasa sebesar $23.4 \%$. Persentase ini lebih tinggi dibandingkan dengan negara-negara seperti Meksiko dimana asupan minuman berkalori $20.1 \%$ untuk remaja dan 22.3\% untuk dewasa dari asupan energi (Barquera et al. 2008).

\section{KESIMPULAN}

Jenis minuman berkalori yang sering diminum berdasarkan kesukaan subjek, yaitu teh tanpa kemasan, teh kemasan, susu kemasan, minuman berkarbonasi, dan jus/sari buah kemasan untuk remaja. Pada dewasa yaitu teh tanpa kemasan, kopi kemasan, minuman berkrabonasi, teh kemasan, jus/sari buah tanpa kemasan.

Jenis minuman berkalori yang memiliki kontribusi tertinggi terhadap asupan energi adalah susu kemasan pada remaja dan teh tanpa kemasan pada dewasa, berturut-turut menyumbang energi sebesar 106 kkal dan 177 kkal. Tidak terdapat perbedaan antara asupan energi minuman berkalori antara remaja dan dewasa $(p>0.05)$. Pada remaja perempuan dan laki-laki terdapat perbedaan yang signifikan, namun pada dewasa laki-laki dan perempuan, tidak terdapat perbedaan yang signifikan $(p>0.05)$.

Total asupan energi minuman berkalori pada remaja sebesar $420 \mathrm{kkal}$, sedangkan untuk dewasa sebesar $450 \mathrm{kkal}$, atau kontribusi asupan tersebut berturut-turut $21.2 \%$ dan $23.4 \%$. Uji korelasi menunjukkan hubungan yang positif antara asupan minuman berkalori dengan total asupan energi baik pada remaja dan dewasa.

Perlunya kewaspadaan peningkatan asupan energi dari minuman berkalori terutama bagi mer- eka yang mengalami kegemukan. Untuk itu perlu edukasi kepada masyarakat bahwa minuman berkalori mempunyai kontribusi pada total asupan energi. Selain itu perlu pengayaan materi pendidikan gizi tentang pilihan jenis minuman untuk mencegah kelebihan asupan energi, mencegah kegemukan, dan dampak buruk lainnya dalam jangka panjang.

\section{DAFTAR PUSTAKA}

Barquera S, Lucia H, Maria L, Juan E, Shu W, Juan A, \& Barry M. 2008. Energy intake from beverages is creasing among Mexican adolescents and adults. J Clin Nutr 2008, 138, 2454-2461.

Bleich SN, Wang YC, Wang Y, and Gortmaker SL. 2009. Increasing consumption of sugar-sweetened beverages among US adults: 1988-1994 to 1999-2004. J Clin Nutr, 89:372-81.

Briawan D, Sedayu TR, \& Ekayanti I. 2011. Kebiasaan minum dan asupan cairan remaja perkotaan. Jurnal Gizi Klinik Indonesia, 8(1), 36-41.

Kleiner S. 1999. Water: an essential but overlooked nutrient. J Am Diet Ass, 1999, 99-102.

Malik VS, Schulze MB, \& Hu FB. 2006. Asupan of sugar-weetened beverages and weight gain: a systematic review. http://www.ajcn.org/ cgi/content/full/84-/2/274?maxtoshow=\&hit $\mathrm{s}=10 \&$ RESULTFORMAT $=\&$ fulltext=beverages $\& \mathrm{~s}$ earchid=1\&FIRSTINDEX=0\&resourcetype=HWC IT [15 september 2010].

Mann J \& Stewart A.T. 2007. Essential of Human Nutrition Third Edition. Oxford University Press inc, USA.

Manz F \& Wentz. 2005. Hydration status in the United States and Germany. Nutr Rev, 63, S55-S61.

Walker WA. 2006. Eat, Play, and Be Healthy. Harvard Medical School, United States.

Weiss D, O'loughlin J, Platt R, \& Paradis G. 2007. Five-year predictors of physical activity decline among adults in low-income communities: a prospective study. http://www.ijbnpa. org/content/4/1/2 [21 Juni 2011].

WHO [World Health Organization]. 2003. Populations with high sugar consumption are at increased risk of chronic disease, South African researchers report. http://www.who.int/ bulletin/releases/2003/PR0803/en/. [21 Juni 2011].

2007. Growth reference 5-19 years. http:// www.who.int/growthref/who2007_bmi_for_ age/en/index.html. [15 September 2010]. 